\title{
Urinary tract infection in cancer patients in a tertiary cancer setting in India: microbial spectrum and antibiotic susceptibility pattern
}

\author{
P Parikh ${ }^{1 *}$, B Bhat $^{2}$ \\ From 3rd International Conference on Prevention and Infection Control (ICPIC 2015) \\ Geneva, Switzerland. 16-19 June 2015
}

\section{Introduction}

In immunocompromised cancer patients, urinary tract infection (UTI) is one of the major causes of fever and morbidity. Screening for UTI is important as atypical presentation is not uncommon in such patients.

\section{Objectives}

To determine the common organisms implicated in UTIs in cancer patients and to study their antimicrobial susceptibility patterns. This would help formulate empirical antibiotic policy in this group of patients.

\section{Methods}

A retrospective analysis of cancer patients suspected to have UTI in the year 2014 was carried out. A total of 497 midstream urine samples collected from cancer patients suspected to have UTI, were sent to the microbiology lab for urine routine and culture examination. Samples were processed as per standard microbiological procedures. All isolates were identified up to species level and antimicrobial susceptibility tests performed as per CLSI guidelines.

\section{Results}

Of the 497 samples processed, 100 were positive for bacterial growth. Overall, E.coli $(40 \%)$ was the predominant isolate followed by Klebsiella pneumoniae (25\%), Pseudomonas aeruginosa (11\%), Enterococcus spp (11\%) and Proteus mirabilis (5\%). Susceptibility of Gram negative bacteria to colistin was highest (100\%) followed by the carbapenems (72\%). Resistance was found to be

${ }^{1}$ Tata Memorial Centre, Mumbai, India

Full list of author information is available at the end of the article higher to the aminoglycosides (46\%), cephalosporins (67\%) and fluoroquinolones (90\%)

\section{Conclusion}

E. coli was the most common organism isolated in cancer patients with UTI. There is trend of increasing resistance to aminoglycosides, cephalosporins and fluoroquinolones among Gram negative bacilli.

\section{Disclosure of interest}

None declared.

\section{Authors' details}

${ }^{1}$ Tata Memorial Centre, Mumbai, India. ${ }^{2}$ Tata Memorial Centre, Mumbai, India.

Published: 16 June 2015

doi:10.1186/2047-2994-4-S1-P221

Cite this article as: Parikh and Bhat: Urinary tract infection in cancer patients in a tertiary cancer setting in India: microbial spectrum and antibiotic susceptibility pattern. Antimicrobial Resistance and Infection Control 2015 4(Suppl 1):P221.

Submit your next manuscript to BioMed Central and take full advantage of:

- Convenient online submission

- Thorough peer review

- No space constraints or color figure charges

- Immediate publication on acceptance

- Inclusion in PubMed, CAS, Scopus and Google Scholar

- Research which is freely available for redistribution

Submit your manuscript at www.biomedcentral.com/submit 